Bull. Mater. Sci., Vol. 19. No. 2, April 1996, pp. 383-392. (C. Printed in India.

\title{
Crystallization of glass in fireclay refractories; part III: Detailed study on the mullite crystal size in the 'synthetic' glass
}

\author{
S P CHAUDHURI and T DATTA \\ Special Ceramics Section, Central Glass and Ceramic Research Institute, Calcutta 700032 , \\ India \\ MS received 31 July 1995; revised 2 November 1995
}

\begin{abstract}
Poor-grade fireclay products contain substantial amount of glass. A glass of similar composition was synthesized, nucleated and heat-treated for crystallization of mullite. The size and size-distribution of mullite crystals, the rate of change of size and the aspect ratio of the crystals were investigated in relation to the nucleating agents and temperature.
\end{abstract}

Keywords. Fireclay; glass; mullite; crystal size-distribution.

\section{Introduction}

It was shown (Chaudhuri and Datta 1996) that the glassy phase in the fireclay products could be crystallized to generate mullite. Besides concentration, other aspects of importance are size, shape and size-distribution of mullite. The communication deals with the study of these microstructural parameters of mullite and the influence of the nucleating agents and heat-treatment temperature on them.

Some earlier investigations (DeVekey and Mazumder 1970; Rogers 1970; Williamson 1970) on other systems, e.g. $\mathrm{CaO}-\mathrm{MgO}-\mathrm{Al}_{2} \mathrm{O}_{3}, \mathrm{SiO}_{2}$ and $\mathrm{CaO}-\mathrm{Al}_{2} \mathrm{O}_{3}-\mathrm{SiO}_{2}$, proved that the crystals which were precipitated from those glasses increased in size with the passage of heating time. Prolonged heating, therefore, caused an increase in the concentration of the crystalline phase as well as an increase in its size. However, the reverse phenomenon was not reported and the size-distribution factor was not taken care of in the studies on glass-crystallization.

\section{Experimental}

The chemical and phase compositions of fireclay, the chemical composition of fireclay glass and the preparation of the synthetic glass with its chemical analysis were reported in part II (Chaudhuri and Datta 1996). The nucleation and crystallization of the synthetic glass were also described there.

\subsection{Size and size-distribution of mullite}

2.1a $X$-ray diffractometry $(X R D)$ : The size of mullite crystals was determined by following the $X$-ray line broadening technique (Jones 1938). A powdered glass sample was mixed with pure quartz powder $(10 \mathrm{wt} . \%$ of the sample). The $1.52 \AA$ line of mullite and $1.817 \AA$ line of quartz were scanned between $60^{\circ}$ and $62^{\circ}(2 \theta)$ for mullite and $49^{\circ}$ and $51^{\circ}(2 \theta)$ for quartz at $(1 / 4)^{\circ} / \mathrm{min}$. The pure diffraction broadening at $1 / 2 \mathrm{height}$ of the mullite peak due to its size was measured and the size was calculated (Henry et al 
1951) with the equation

$$
D_{h k l}=\frac{0 \cdot 9 \lambda}{\beta_{1 / 2} \cos \theta},
$$

the symbols have usual meaning.

2.1b Scanning electron microscopy (SEM): A glass sample was broken and the broken surface was etched with $40 \% \mathrm{HF}$ for $1 \mathrm{~min}$ at room temperature. The surface

Table 1. Size of mullite crystals in the samples containing $\mathrm{Cr}_{2} \mathrm{O}_{3}$.

\begin{tabular}{|c|c|c|c|c|c|}
\hline \multirow{2}{*}{$\begin{array}{l}\text { Nucleating } \\
\text { agent } \\
\mathrm{Cr}_{2} \mathrm{O}_{3}\end{array}$} & \multirow{2}{*}{$\begin{array}{c}\text { Heating } \\
\text { temp. } \rightarrow \\
\text { Heating } \\
\text { time }(h) \\
\downarrow\end{array}$} & \multicolumn{4}{|c|}{$\begin{array}{l}\text { Size of mullite crystals }(\mu) \\
\text { at temp. }\end{array}$} \\
\hline & & $1110^{\circ} \mathrm{C}$ & $1130^{\circ} \mathrm{C}$ & $1150^{\circ} \mathrm{C}$ & $1170^{\circ} \mathrm{C}$ \\
\hline \multirow{6}{*}{$0.5 \mathrm{wt} . \%$} & 5 & 0.0816 & 0.0951 & 0.0762 & 0.1397 \\
\hline & 15 & 0.2712 & 0.0922 & 0.0699 & 0.1153 \\
\hline & 25 & 0.1317 & $0 \cdot 1962$ & $0 \cdot 1317$ & $0 \cdot 1085$ \\
\hline & 35 & 0.0807 & 0.1537 & 0.0756 & 0.2778 \\
\hline & 5 & 0.1356 & 0.0738 & 0.4010 & $0 \cdot 1048$ \\
\hline & 15 & 0.0815 & 0.1153 & 0.0607 & 0.1153 \\
\hline \multirow[t]{3}{*}{$1 \mathrm{wt} . \%$} & 25 & $0 \cdot 1487$ & 0.1182 & $0 \cdot 2305$ & $0 \cdot 1442$ \\
\hline & 35 & $0 \cdot 2975$ & 0.3547 & 0.0768 & 0.1656 \\
\hline & 5 & 0.1647 & $0 \cdot 3843$ & $0 \cdot 1072$ & 0.1441 \\
\hline \multirow[t]{3}{*}{1.5 wt. $\%$} & 15 & 0.1615 & 0.2305 & $0 \cdot 1962$ & 0.2306 \\
\hline & 25 & $0 \cdot 1845$ & $0 \cdot 1962$ & 0.0144 & 0.0023 \\
\hline & 35 & 0.0904 & 0.0862 & 0.0768 & 0.1757 \\
\hline
\end{tabular}

Table 2. Size of mullite crystals in the samples containing $\mathrm{V}_{2} \mathrm{O}_{5}$.

\begin{tabular}{|c|c|c|c|c|c|}
\hline \multirow{2}{*}{$\begin{array}{l}\text { Nucleating } \\
\text { agent } \\
\mathrm{V}_{2} \mathrm{O}_{5}\end{array}$} & \multirow{2}{*}{$\begin{array}{l}\text { Heating } \\
\text { temp. } \rightarrow \\
\text { Heating } \\
\text { time (h) } \\
\downarrow \downarrow\end{array}$} & \multicolumn{4}{|c|}{$\begin{array}{l}\text { Size of mullite crystals }(\mu) \\
\text { at temp. }\end{array}$} \\
\hline & & $1110^{\circ} \mathrm{C}$ & $1130^{\circ} \mathrm{C}$ & $1150^{\circ} \mathrm{C}$ & $1170^{\circ} \mathrm{C}$ \\
\hline \multirow{4}{*}{1 wt. $\%$} & 5 & 0.1770 & 0.0884 & $0 \cdot 1213$ & 0.1263 \\
\hline & 15 & $0 \cdot 1395$ & 0.0838 & 0.0775 & 0.1845 \\
\hline & 25 & 0.3547 & $0 \cdot 0683$ & $0 \cdot 1845$ & 0.1264 \\
\hline & 35 & 0.0809 & $0-1397$ & $0 \cdot 1182$ & 0.0872 \\
\hline \multirow{4}{*}{3 wt. $\%$} & 5 & $0 \cdot 1139$ & 0.0710 & 0.1229 & 0.1111 \\
\hline & 15 & $0 \cdot 1050$ & $0 \cdot 1317$ & 0.0802 & 0.1537 \\
\hline & 25 & 0.0911 & 0.0683 & 0.1153 & 0.0645 \\
\hline & 35 & 0.1246 & 0.1153 & 0.0693 & 0.0878 \\
\hline \multirow{4}{*}{$5 w t . \%$} & 5 & 0.0688 & 0.1317 & 0.0756 & 0.1025 \\
\hline & 15 & 0.1629 & $0 \cdot 0795$ & 0.0437 & 0.1845 \\
\hline & 25 & $0 \cdot 086 !$ & 0.1230 & 0.0838 & 0.1264 \\
\hline & 35 & 0.0846 & 0.0768 & 0.1773 & 0.1198 \\
\hline
\end{tabular}


Table 3. Size of mullite crystals in the samples containing $\mathrm{TiO}_{2}$.

\begin{tabular}{|c|c|c|c|c|c|}
\hline \multirow{4}{*}{$\begin{array}{l}\text { Nucleating } \\
\text { agent } \\
\mathrm{TiO}_{2} \\
{ }_{-}\end{array}$} & \multirow{3}{*}{$\begin{array}{c}\text { Heating } \\
\text { temp. } \rightarrow \\
\text { Heating } \\
\text { time (h) } \\
\downarrow\end{array}$} & \multicolumn{4}{|c|}{$\begin{array}{c}\text { Size of mullite crystals }(\mu) \\
\text { at temp. }\end{array}$} \\
\hline & & $\ldots-\cdots$ & $\cdots$ & 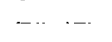 & $-\quad-\quad \cdots-$ \\
\hline & & $1110 \mathrm{C}$ & $1130^{\prime} \mathrm{C}$ & $1150^{\circ} \mathrm{C}$ & $1170^{\circ} \mathrm{C}$ \\
\hline & $-\quad-\quad \ldots$ & $\cdots-\cdots-$ & $--\quad--$ & -- & -... - - - \\
\hline \multirow{4}{*}{$8 w t . \%$} & 5 & $0 \cdot 1844$ & $0 \cdot 3294$ & $0 \cdot 0560$ & $0 \cdot 1263$ \\
\hline & 15 & $0 \cdot 1164$ & 0.0922 & $0 \cdot 1962$ & $0 \cdot 3075$ \\
\hline & 25 & 0.1125 & 0.0862 & 0.3074 & $0 \cdot 1264$ \\
\hline & 35 & $0 \cdot 1246$ & 0.0941 & 0.1182 & $0 \cdot 3660$ \\
\hline \multirow{4}{*}{$10 \mathrm{wt} . \%$} & 5 & $0 \cdot 3547$ & $0 \cdot 2196$ & $0 \cdot 6588$ & 0.0922 \\
\hline & 15 & 0.2562 & $0-0941$ & $0-1317$ & 0.7686 \\
\hline & 25 & 0.0615 & $0 \cdot 1487$ & $0 \cdot 1441$ & 0.0645 \\
\hline & 35 & $0 \cdot 1060$ & $0 \cdot 1962$ & 0.0536 & 0.2562 \\
\hline \multirow{4}{*}{$12 w t . \%$} & 5 & 0.8384 & $0 \cdot 1708$ & $0 \cdot 1962$ & 0.6588 \\
\hline & 15 & 0.3416 & $0 \cdot 3843$ & 0.5693 & 0.2050 \\
\hline & 25 & 00768 & 0.2713 & $0 \cdot 1708$ & 0.0838 \\
\hline & 35 & $0 \cdot 3689$ & 0.2755 & 0.7686 & 0.3827 \\
\hline
\end{tabular}

Table 4. Size of mullite crystals in the samples containing $\left(\mathrm{Cr}_{2} \mathrm{O}_{3}+\mathrm{V}_{2} \mathrm{O}_{5}\right)$.

\begin{tabular}{|c|c|c|c|c|c|}
\hline \multirow{4}{*}{$\begin{array}{l}\text { Nucleating } \\
\text { agent } \\
\left(\mathrm{Cr}_{2} \mathrm{O}_{3}+\mathrm{V}_{2} \mathrm{O}_{5}\right) \\
\end{array}$} & $\begin{array}{l}\text { Heating } \\
\text { temp. } \rightarrow \\
\text { Heating }\end{array}$ & \multicolumn{4}{|c|}{$\begin{array}{c}\text { Size of mullite crystals }(\mu) \\
\text { at temp. }\end{array}$} \\
\hline & time (h) & $\ldots \ldots$ & - & $-\ldots$ & $--\cdot-$ \\
\hline & $\downarrow$ & $1110^{\circ} \mathrm{C}$ & $1130 \mathrm{C}$ & $1150 \mathrm{C}$ & $1170^{\circ} \mathrm{C}$ \\
\hline & - & $--\quad \cdots$ & $-\cdots$ & -...-- & $-\overline{-}-\overline{1}$ \\
\hline & 5 & 0.1419 & 0.2365 & 0.0932 & $0-0887$ \\
\hline \multirow{3}{*}{$(1+1) w t \%$} & 15 & 0.3689 & 0.0775 & $0 \cdot 1153$ & 0.2005 \\
\hline & 25 & 0.1153 & 0.0795 & 0.0913 & 0.0923 \\
\hline & 35 & 0.0895 & 0.0854 & 0.0823 & 0.1178 \\
\hline \multirow{4}{*}{$(1 \cdot 5+3)$ wt. $\%$} & 5 & 0.0932 & $0 \cdot 1060$ & 0.0971 & $0 \cdot 0756$ \\
\hline & 15 & 1.0247 & 0.0636 & 0.4611 & $0 \cdot 1213$ \\
\hline & 25 & 0.0838 & $0 \cdot 1085$ & $0 \cdot 1002$ & $0 \cdot 1230$ \\
\hline & 35 & 0.0698 & 0.0632 & 0.0694 & 0.0971 \\
\hline \multirow{4}{*}{$(0-5+5)$ wt. $\%$} & 5 & 0.0688 & 0.0720 & $0 \cdot 1060$ & 0.2427 \\
\hline & 15 & 0.09223 & 0.0611 & 0.0838 & 0.8385 \\
\hline & 25 & $0 \cdot 1025$ & 0.0795 & $0 \cdot 1198$ & 0.1488 \\
\hline & 35 & $0-0951$ & 0.0650 & 0.0932 & $0 \cdot 4521$ \\
\hline
\end{tabular}

was gold coated and observed under SEM to take micrographs from different places. The length and breadth of a large number of mullite crystals were measured and also the aspect ratio of each crystal.

The histogram and the distribution curve were drawn for each sample on the same plot. The skewness factor was also calculated (Goulden 1952) from the following:

$$
\text { Skewness }=\frac{\text { Mean size }- \text { modal size }}{\text { Standard deviation }} \text {. }
$$


Table 5. Size of mullite crystals in the samples containing $\left(\mathrm{TiO}_{2}+\mathrm{V}_{2} \mathrm{O}_{5}\right)$.

\begin{tabular}{|c|c|c|c|c|c|}
\hline \multirow{2}{*}{$\begin{array}{l}\text { Nucleating } \\
\text { agent } \\
\left(\mathrm{TiO}_{2}+\mathrm{V}_{2} \mathrm{O}_{5}\right)\end{array}$} & \multirow{2}{*}{$\begin{array}{c}\text { Heating } \\
\text { temp. } \rightarrow \\
\text { Heating } \\
\text { time (h) } \\
\downarrow\end{array}$} & \multicolumn{4}{|c|}{$\begin{array}{c}\text { Size of mullite crystals }(\mu) \\
\text { at temp. }\end{array}$} \\
\hline & & $1110^{\circ} \mathrm{C}$ & $1130^{\circ} \mathrm{C}$ & $1150^{\circ} \mathrm{C}$ & $1170^{\circ} \mathrm{C}$ \\
\hline \multirow{5}{*}{$(10 \cdot 0+1 \cdot 0) w t . \%$} & 5 & 0.8384 & $0 \cdot 1397$ & $0 \cdot 1098$ & 0.0454 \\
\hline & 15 & 0.5764 & 0.0518 & 0.4611 & $0 \cdot 1441$ \\
\hline & 25 & 0.0709 & 0.0801 & 0.0951 & $0 \cdot 6148$ \\
\hline & 35 & $0 \cdot 1947$ & 0.0922 & 0.6587 & 0.2186 \\
\hline & 5 & $0 \cdot 1019$ & 0.0941 & 0.0932 & $0 \cdot 1125$ \\
\hline \multirow{3}{*}{$(8 \cdot 0+5.0) w t . \%$} & 15 & 0.6588 & 0.0726 & 0.0485 & 0.4010 \\
\hline & 25 & 0.0461 & 0.0460 & 0.1048 & 0.0838 \\
\hline & 35 & 0.0636 & 0.0559 & 0.1774 & 0.6782 \\
\hline \multirow{4}{*}{$(12 \cdot 0+3 \cdot 0) w t . \%$} & 5 & 0.2562 & $0 \cdot 1441$ & $0 \cdot 1281$ & 0.2305 \\
\hline & 15 & 0.1845 & $0 \cdot 1230$ & 0.0542 & 0.4392 \\
\hline & 25 & 0.0990 & 0.0862 & $0 \cdot 1677$ & 0.2250 \\
\hline & 35 & 0.3617 & $0 \cdot 2635$ & $0 \cdot 2306$ & 0.4081 \\
\hline
\end{tabular}

Table 6. Rate of size change of mullite crystals in the samples.

\begin{tabular}{|c|c|c|c|c|c|}
\hline \multirow{2}{*}{$\begin{array}{l}\text { Nucleating } \\
\text { agent } \\
\text { (N.A.) }\end{array}$} & \multirow{2}{*}{$\begin{array}{c}\text { Conc. of } \\
\text { N.A. } \\
\text { (wt. } \% \text { ) }\end{array}$} & \multicolumn{4}{|c|}{$\begin{array}{c}\text { Rate of size change }(K),\left[(\mu / \mathrm{min}) \times 10^{5}\right] \\
\text { at temp. }\end{array}$} \\
\hline & & $1110^{\circ} \mathrm{C}$ & $1130^{\circ} \mathrm{C}$ & $1150^{\circ} \mathrm{C}$ & $1170^{\circ} \mathrm{C}$ \\
\hline \multirow{3}{*}{$\mathrm{Cr}_{2} \mathrm{O}_{3}$} & 0.5 & $16 \cdot 6$ & $3 \cdot 3$ & $1 \cdot 1$ & $2 \cdot 8$ \\
\hline & $1 \cdot 0$ & 400 & $40-0$ & $30 \cdot 0$ & $3 \cdot 3$ \\
\hline & $1 \cdot 5$ & $4 \cdot 7$ & $13-3$ & $2 \cdot 3$ & $17 \cdot 5$ \\
\hline \multirow{3}{*}{$\mathrm{V}_{2} \mathrm{O}_{5}$} & 1.0 & $5 \cdot 8$ & $2 \cdot 3$ & $3 \cdot 9$ & $7 \cdot 7$ \\
\hline & $3 \cdot 0$ & $1 \cdot 7$ & $10 \cdot 0$ & $3 \cdot 3$ & $8 \cdot 3$ \\
\hline & $5 \cdot 0$ & $8 \cdot 8$ & $2 \cdot 9$ & $11 \cdot 7$ & $5 \cdot 8$ \\
\hline \multirow{3}{*}{$\mathrm{TiO}_{2}$} & $8 \cdot 0$ & $3 \cdot 3$ & 67 & $5 \cdot 0$ & $8 \cdot 3$ \\
\hline & 100 & $14 \cdot 4$ & $8 \cdot 7$ & $43 \cdot 3$ & $7 \cdot 2$ \\
\hline & $12-0$ & $50-4$ & $16 \cdot 6$ & 41.7 & $62-5$ \\
\hline \multirow[t]{3}{*}{$\left(\mathrm{Cr}_{2} \mathrm{O}_{3}+\mathrm{V}_{2} \mathrm{O}_{5}\right)$} & $(1 \cdot 0+1 \cdot 0)$ & $26 \cdot 6$ & $13 \cdot 3$ & $3 \cdot 3$ & $8 \cdot 9$ \\
\hline & $(1.5+3.0)$ & $3 \cdot 3$ & $8 \cdot 3$ & $33 \cdot 3$ & $5 \cdot 5$ \\
\hline & $(0 \cdot 5+5 \cdot 0)$ & $5 \cdot 3$ & $3 \cdot 3$ & $3 \cdot 3$ & $4 \cdot 0$ \\
\hline \multirow[t]{3}{*}{$\left(\mathrm{TiO}_{2}+\mathrm{V}_{2} \mathrm{O}_{5}\right)$} & $(10 \cdot 0+1 \cdot 0)$ & $40 \cdot 3$ & $6 \cdot 7$ & $53 \cdot 2$ & $35 \cdot 5$ \\
\hline & $(8 \cdot 0+5 \cdot 0)$ & $6 \cdot 6$ & $4 \cdot 0$ & $2 \cdot 5$ & $33 \cdot 3$ \\
\hline & $(12 \cdot 0+3 \cdot 0)$ & $12 \cdot 5$ & $5 \cdot 6$ & $5 \cdot 6$ & $33 \cdot 3$ \\
\hline
\end{tabular}

\subsection{Rate of change of mullite crystal size}

A glass sample containing one concentration of a nucleating agent yielded four samples when heat-treated for four different time periods at one temperature. The size of mullite crystals was then plotted against the time and the rate of size change was determined from the slope. 
Table 7. Activation energy of rate of size change of mullite in the samples.

\begin{tabular}{lcc}
\hline $\begin{array}{l}\text { Nucleating } \\
\text { agent } \\
\text { (N.A.) }\end{array}$ & $\begin{array}{c}\text { Conc. of } \\
\text { N.A. } \\
\text { (wt.\%) }\end{array}$ & $\begin{array}{c}\text { Activation energy } \\
\text { (Kcal/mol) }\end{array}$ \\
\hline & $0 \cdot 5$ & $137 \cdot 3$ \\
$\mathrm{Cr}_{2} \mathrm{O}_{3}$ & $1 \cdot 0$ & $73 \cdot 2$ \\
& $1 \cdot 5$ & $183 \cdot 5$ \\
& $1 \cdot 0$ & $45 \cdot 7$ \\
$\mathrm{~V}_{2} \mathrm{O}_{5}$ & $3 \cdot 0$ & $36 \cdot 6$ \\
& $5 \cdot 0$ & $137 \cdot 3$ \\
& $8 \cdot 0$ & $91 \cdot 5$ \\
$\mathrm{TiO}_{2}$ & $10 \cdot 0$ & $30 \cdot 5$ \\
& $12 \cdot 0$ & $137 \cdot 3$ \\
& $(1 \cdot 0+1 \cdot 0)$ & $91 \cdot 5$ \\
$\left(\mathrm{Cr}_{2} \mathrm{O}_{3}+\mathrm{V}_{2} \mathrm{O}_{5}\right)$ & $(1 \cdot 5+3 \cdot 0)$ & $45 \cdot 5$ \\
& $(0 \cdot 5+5 \cdot 0)$ & $36 \cdot 5$ \\
& $(10 \cdot 0+1 \cdot 0)$ & $18 \cdot 3$ \\
$\left(\mathrm{TiO}_{2}+\mathrm{V}_{2} \mathrm{O}_{5}\right)$ & $(8 \cdot 0+5 \cdot 0)$ & $91 \cdot 5$ \\
& $(12 \cdot 0+3 \cdot 0)$ & $137 \cdot 3$ \\
\hline
\end{tabular}

Table 8. Aspect ratio of mullite crystals and skewness of size-distribution curves.

\begin{tabular}{lcc}
\hline $\begin{array}{l}\text { Nucleating } \\
\text { agent }\end{array}$ & Range of aspect ratio & $\begin{array}{c}\text { Skewness of size } \\
\text { distribution curve }\end{array}$ \\
\hline $\mathrm{Cr}_{2} \mathrm{O}_{3}$ & $1.90-3.14$ & 0.235 \\
$\mathrm{~V}_{2} \mathrm{O}_{5}$ & $2 \cdot 06-3.60$ & 0.032 \\
$\mathrm{TiO}_{2}$ & $2 \cdot 13-3.93$ & 0.143 \\
$\left(\mathrm{Cr}_{2} \mathrm{O}_{3}+\mathrm{V}_{2} \mathrm{O}_{5}\right)$ & $2 \cdot 37-3.33$ & 0.150 \\
$\left(\mathrm{TiO}_{2}+\mathrm{V}_{2} \mathrm{O}_{5}\right)$ & $2.64-4.06$ & 0.014 \\
\hline
\end{tabular}

\section{Results}

The sizes of mullite crystals in different samples are presented in tables $1-5$. The rates of change of crystal size $(K)$ are included in table 6 . The temperature dependence of the rate was calculated from the Arrhenius plot,

$$
\log _{10} K \text { vs } 1 / T \text {. }
$$

A representative plot is shown in figure 1. The activation energy values are compiled in table 7 . The skewness factors and aspect ratios ( $\min$ and max in the range) are given in table 8. The influence of radius and charge of cations of nucleating agents on the size of mullite crystals is displayed in figures 2 and 3, respectively and also in table 9 . The relationship at the minimum, intermediate and maximum concentrations of the oxides are shown by curves 1,2 and 3 , in figures 2 and 3 . 
Table 9. Effect of radius and charge of cations of nucleating agents on the avg. size of mullite crystal.

\begin{tabular}{lcccc}
\hline $\begin{array}{l}\text { Nucleating } \\
\text { agent } \\
\text { (N.A.) }\end{array}$ & $\begin{array}{c}\text { Radius of } \\
\text { Conc. of N.A. } \\
(\text { wt. } \%)\end{array}$ & $\begin{array}{c}\text { cation of } \\
\text { N.A. } \\
(\AA)\end{array}$ & $\begin{array}{c}\text { Charge of } \\
\text { cation of } \\
\text { N.A. }\end{array}$ & $\begin{array}{c}\text { Avg. size of } \\
\text { mullite crystal } \\
(\mu)\end{array}$ \\
\hline & 0.5 & & & 0.1310 \\
$\mathrm{Cr}_{2} \mathrm{O}_{3}$ & 1.0 & 0.63 & $3^{+}$ & 0.1640 \\
& 1.5 & & & 0.1585 \\
$\mathrm{~V}_{2} \mathrm{O}_{5}$ & 1.0 & & & 0.1349 \\
& 3.0 & 0.59 & $5^{+}$ & 0.1016 \\
& 5.0 & & & 0.1079 \\
$\mathrm{TiO}_{2}$ & 8.0 & & $4^{+}$ & 0.1715 \\
& 10.0 & 0.68 & & 0.2254 \\
& 12.0 & & & 0.3602 \\
\hline
\end{tabular}

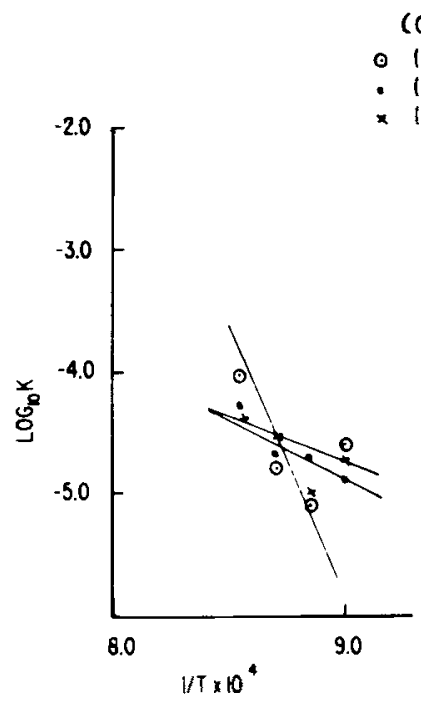

Figure 1. Arrhenius plot for rate of size change of mullite $(K)$.

\section{Discussion}

The results given in tables 1-5 showed that irrespective of time and temperature of heat-treatment, and, the concentration of nucleating oxides, $\mathrm{V}_{2} \mathrm{O}_{5}$ favoured formation of small crystals and $\mathrm{TiO}_{2}$ the big crystals. But the crystal size due to $\mathrm{Cr}_{2} \mathrm{O}_{3}$ stood in between. The use of $\mathrm{V}_{2} \mathrm{O}_{5}$ in combination with either $\mathrm{Cr}_{2} \mathrm{O}_{3}$ or $\mathrm{TiO}_{2}$ helped reduction of crystal size that grew in the presence of $\mathrm{Cr}_{2} \mathrm{O}_{3}$ and $\mathrm{TiO}_{2}$ alone.

At any temperature the crystal size decreased with the increase in heating time. Consequently, the rate of size change as reported in table 6 implied the rate of decrease or disappearance of mullite crystals, i.e. higher rate values meant faster decrease of size.

Mullite crystals in the samples are displayed in figures $4 \mathrm{a}-\mathrm{e}$. It appeared from this figure and table 6 that except at $1130^{\circ} \mathrm{C}, \mathrm{Cr}_{2} \mathrm{O}_{3}$ was responsible for the lowest rate of size 


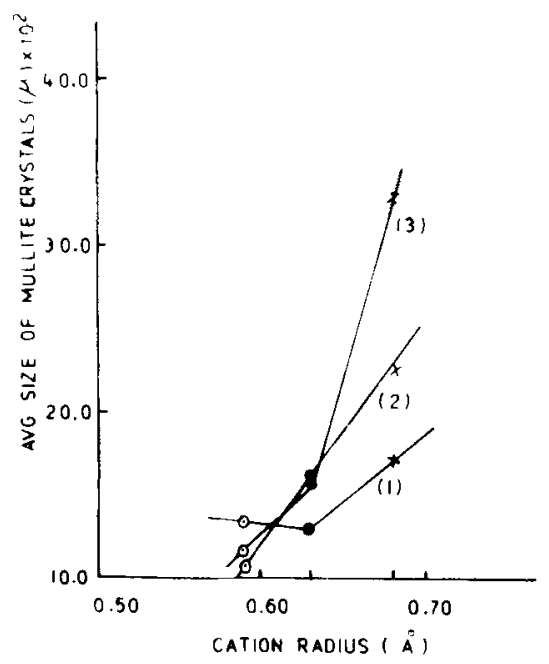

$$
\begin{aligned}
& \text { - cr } \\
& \times \quad T_{1} \\
& -\quad v
\end{aligned}
$$

Figure 2. Dependence of average size of mullite crystals on the cation radius of nucleating agent at (1) minimum, (2) intermediate and (3) maximum concentration of it.

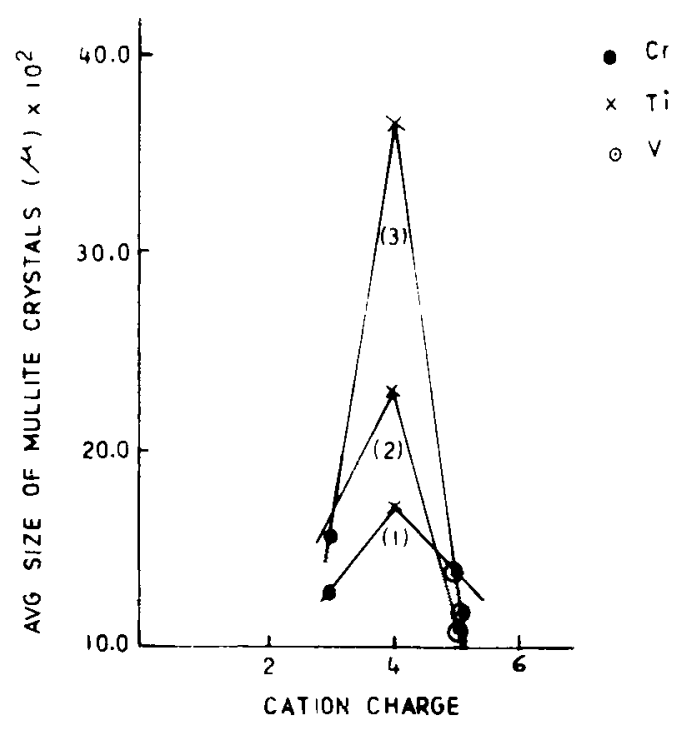

Figure 3. Dependence of average size of mullite crystals on the cation charge of nucleating agent at (1) minimum, (2) intermediate and (3) maximum concentration of it.

change, $\mathrm{V}_{2} \mathrm{O}_{5}$ for the highest rate and $\mathrm{TiO}_{2}$ for the rate in between. Therefore, the size of mullite crystals decreased from samples containing $\mathrm{Cr}_{2} \mathrm{O}_{3}$ to those containing $\mathrm{V}_{2} \mathrm{O}_{5}$.

The lowest and highest rates of decrease of mullite crystal size with $\mathrm{Cr}_{2} \mathrm{O}_{3}$ and $\mathrm{V}_{2} \mathrm{O}_{5}$, respectively are also justified by the highest $(131 \mathrm{Kcal} / \mathrm{mol})$ and the lowest $(73.2 \mathrm{Kcal} / \mathrm{mol})$ average values of activation energies of rate of crystal size change of the samples with $\mathrm{Cr}_{2} \mathrm{O}_{3}$ and $\mathrm{V}_{2} \mathrm{O}_{5}$, respectively. The effect of $\mathrm{TiO}_{2}$, in this respect, assumed the intermediate position $(86.2 \mathrm{Kcal} / \mathrm{mol})$. 
It was observed that $\mathrm{TiO}_{2}$ helped in the crystallization of longer needles of mullite as compared to those crystallized by $\mathrm{V}_{2} \mathrm{O}_{5}$ and $\mathrm{Cr}_{2} \mathrm{O}_{3}$ in the samples. This is realized from the aspect ratios (table 8) that decreased from $\mathrm{TiO}_{2}$ to $\mathrm{Cr}_{2} \mathrm{O}_{3}$.
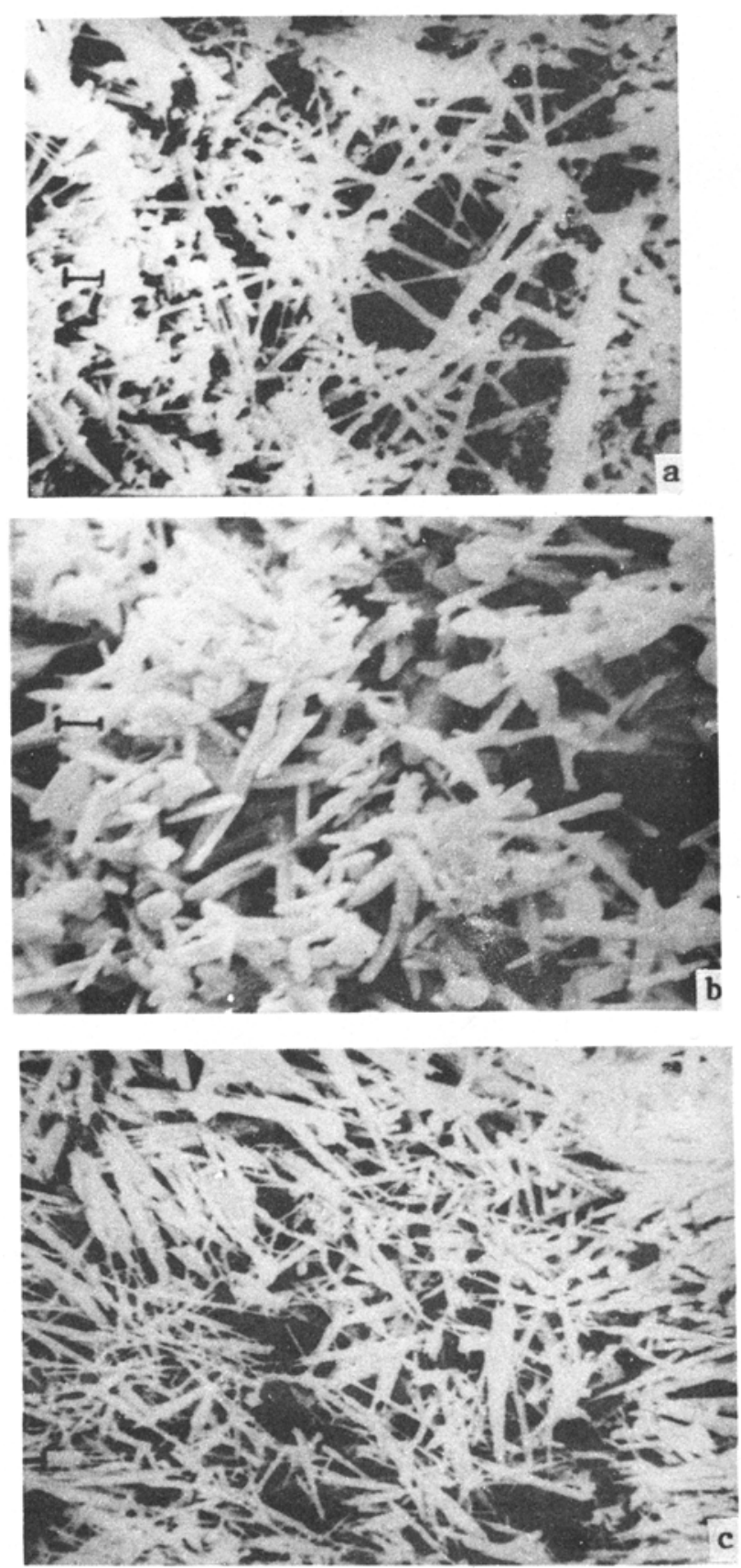

Figure 4. a-c. 

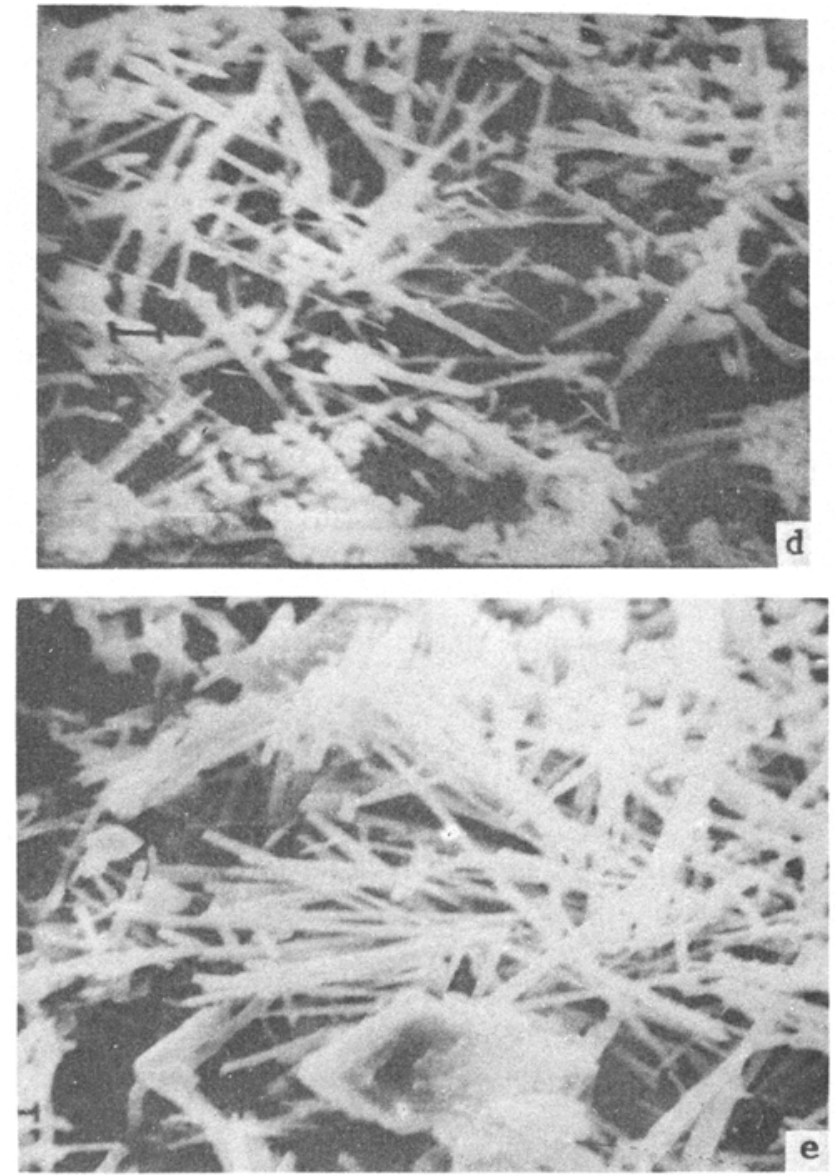

Figure 4. SEM micrographs of samples containing (a) $\mathrm{Cr}_{2} \mathrm{O}_{3}$, (b) $\mathrm{V}_{2} \mathrm{O}_{5}$, (c) $\mathrm{TiO}_{2}$, (d) $\left(\mathrm{Cr}_{2} \mathrm{O}_{3}+\mathrm{V}_{2} \mathrm{O}_{5}\right)$ and $(\mathrm{e})\left(\mathrm{TiO}_{2}+\mathrm{V}_{2} \mathrm{O}_{5}\right)(\mathrm{Bar}=1 \cdot 0 \mu)$.

The size-distribution of mullite crystals in all the samples was found to be asymmetric. The asymmetry changed with the nature of the nucleating oxides used for crystallization. It was measured by the skewness factor (table 8 ) and the values indicated that the effect of these oxides on asymmetry followed the series

$$
\mathrm{Cr}_{2} \mathrm{O}_{3}>\mathrm{TiO}_{2}>\mathrm{V}_{2} \mathrm{O}_{5}
$$

Compactness of crystal arrangement varies with the asymmetry. So, the effect of the oxides on compactness of crystal arrangement in samples followed the above series.

The cations of the nucleating oxides served as islands in the glass to precipitate crystals on them and thus crystal size was dependent on cation size. The smallest $\mathrm{V}^{5+}$ ion and the largest $\mathrm{Ti}^{4+}$ ion therefore, initiated growth of the smallest and the largest crystals, respectively while $\mathrm{Cr}^{3+}$ ion favoured formation of crystals of medium size (figure 2, table 9).

Except in some unusual cases, the higher valency, cations are smaller in size (Moeller 1952). The crystal size-cation charge relationship (figure 3 ) is opposite to that found in figure 2. 
In this study (described in parts II and III) it was desired to estimate the concentration of mullite and to measure the size (and size-distribution) of mullite crystals simultaneously in the samples as well as the rates of change of concentration of mullite and its size. Unlike other work, it was observed that in a sample while concentration of mullite increased the size of mullite crystal decreased.

The rate of crystallization of mullite $\left(K^{\prime}\right)$ was of the order of $\left(\times 10^{-3}\right) \mathrm{wt} \%$ per min (table 7 of Part II) but the rate of change of size of mullite crystal $(K)$ was of the order of $\left(\times 10^{-5}\right) \mu$ per min (table 6 of Part III). The rate of rise of concentration of mullite was 100 times faster than the rate of decrease of size of mullite crystal and, therefore, generation of mullite from glass always far exceeded the dissolution of mullite in the same glass. These two rates would gradually come to equilibrium after prolonged heat-treatment of the sample.

The equilibrium microstructure of the sample should consist of good concentration of mullite crystals of small size. Such microstructure is very favourable for good mechanical and thermal properties of a ceramic body.

This expectation is partially fulfilled in this investigation.

\section{Conclusions}

(1) The size of mullite crystals increased from $\mathrm{V}_{2} \mathrm{O}_{5}$-containing sample to $\mathrm{TiC}_{2}$ containing samples. Irrespective of nucleating agent and heat-treatment temperature, the crystal size decreased with longer heating time.

(2) The rate of reduction of crystal size was influenced by the nucleating agent.

(3) The size-distribution of mullite crystals was asymmetric in all the samples and asymmetry (skewness factor) decreased from $\mathrm{Cr}_{2} \mathrm{O}_{3}$ to $\mathrm{V}_{2} \mathrm{O}_{5}$.

(4) The acicularity of mullite crystals (aspect ratio) decreased from samples containing $\mathrm{TiO}_{2}$ to those containing $\mathrm{Cr}_{2} \mathrm{O}_{3}$.

(5) A nucleating agent of smaller cation (such as $\mathrm{V}^{5+}$ ) helped crystallization of smaller mullite crystals.

\section{Acknowledgement}

One of the authors (TD) is grateful to CSIR, New Delhi for a research fellowship granted to him for doing this work.

\section{References}

Chaudhuri S P and Datta T 1996 Bull. Mater. Sci. 19373

Devekey R C and Mazumder A J 1970 Miner. Mag. 37771

Goulden C H 1952 Methods of statistical analysis (Calcutta: Asia Publishing House) p. 33

Henry N F, Lipson H and Wooster W A 1951 The interpretation of X-ray diffraction photographs (London: McMillan) p. 212

Jones F W 1938 Proc. R. Soc. A16 16

Moeller T 1952 Inorganic chemistry-An advanced textbook (New York: Wiley) p. 127

Rogers P S 1970 Miner. Mag. 37741

Williamson J 1970 Miner. Mag. 37760 